\title{
INNOVATION MANAGER AND HIS POSITION IN COMPANY
}

\author{
KATEŘINA HRAZDILOVÁ BOČKOVÁ
}

\section{INTRODUCTION}

Innovation is the magic word in business and public administration. However, huge potential for improvement has only minimal use, even in companies where ideas and suggestions are more or less systematically collected and implemented and some authors rewarded.

While domestic companies often do not pay sufficient attention to innovation management, this area has been gaining a key role in corporate strategy abroad. Czech top managers should therefore master the principles of innovation.

At the moment, the personality is no longer seen as a labour force only to perform specific commands within the given time span, but it is treated in qualitatively higher form of leadership and human potential is utilized in more meaningful way. More space is devoted to professional as well as personal development of personality. Greater emphasis is placed on personal experience, skills, will and discretion of employees. Creative skills are becoming building stones to implement and solve changes, so much needed in this millennium. The value of the human factor increases significantly. If managers want to be successful, they must understand the staff not only as an entity with its intellectual capital, but also the adaptation to the group and sense of interpersonal relations. Human resource management is subject to very high new claims, which should ensure the company's competitiveness.

The innovation process in the firm covers a wide range of activities undertaken from the very initial idea to putting them in life. It thus includes research and development, industrial-legal protection, the establishment of production and final application of innovations in practice. Innovation and innovation policy in the company is not something that would be widely extended, what would be a normal part of the organization and functioning of the company. The problem is already in the beginning, when the fact is concerned that not all entrepreneurs and managers are interested in new theories, practices and requirements. Among them are many who have ingrown their managerial roots in the former industrial period, regardless of age. An essential characteristic of such people is the idea that for successful business a person needs to work a lot and deliver an honest product. This is now of course no longer true (Christensen, 1997). 
The current innovation management system is shown in Figure 1.

Qualifications and personal skills of innovation managers are one of the main conditions for further development of the company. It is clear that successful business strategy is built on the so-called evolutionary management, the managers who are oriented to deal with situations and have the ability to create and develop visions with appropriate time horizon.

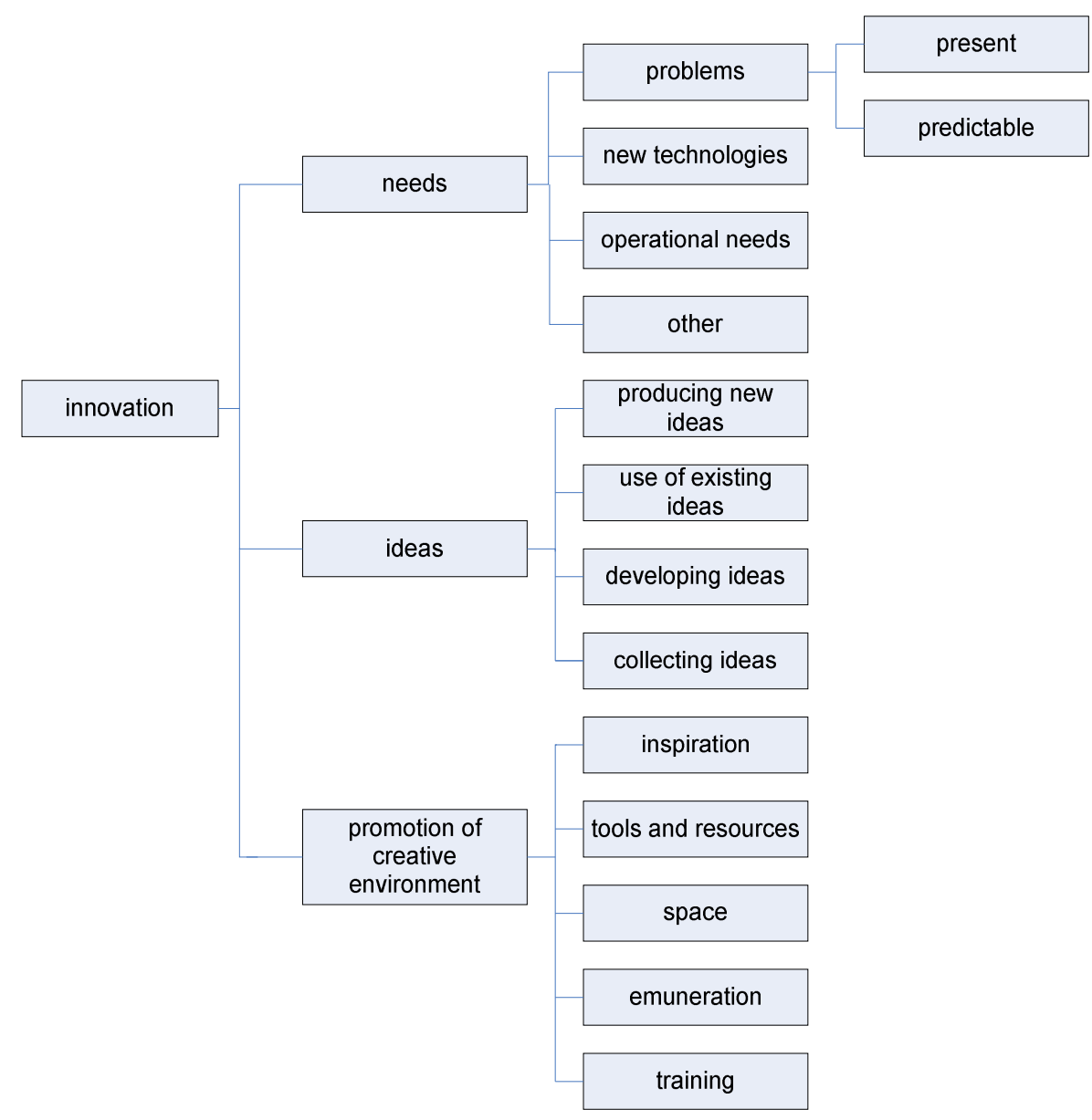

Figure 1-Innovation management system (Christensen, 1997)

\section{METHODOLOGY}

An innovation manager should be equipped with comprehensive knowledge of the structure and dynamics of company systems, he should have an overview of the key causes and factors creating an innovative environment, both to be an expert in the field of processes for managing the entire life cycle of innovation and determination of their priorities, particularly in terms of value added and reusability as written in (Hofbruckerová, 2010).

The main task of innovation managers should consist of managing and controlling changes in the organization based on the responses to internal and external stimuli of environment, in which the organization operates, familiarization with a new look at the organization from the perspective of the 
processes. The process view should enable to assure the flexibility and effectiveness of organization responding to changes and thus survive in this hyper-competitive information age, where success of both individuals and organizations depends on important measures such as availability, management and proper communication as well as information sharing. In entrepreneurship where an amount of knowledge and information needed to ensure business is increasing, the transition to a process-managed organization is essential for the coming millennium (Jaterková, 2008).

Each company is interested in improving the way is conducts its business, wants to produce goods and services more efficiently and thus increase its profits. Each manager should be aware that meeting these goals is part of his work.

The primary aim of the paper is to analyze the characteristics of innovation manager in the market section focused on "Production, sale and operation of amusement and gaming technology".

\section{Secondary aims are:}

- analysis of the qualities of innovation manager from the perspective of his own personality assessment,

- definition of ideal qualities of innovation manager,

- definition of the position of innovation manager in company.

A questionnaire survey was used to explore the qualities of innovation manager working in "Production, sale and operation of amusement and gaming technology". A scale questionnaire was chosen for this purpose. The spectrum represents the degree of agreement expressed by the evaluation scale. Its various levels are coded and can be summarized and averaged in the end. The simplicity of filling scale questions and easy workability of results were decisive factors for selecting this form of data survey.

The selected questionnaire consists of evaluation scale ranging from 1 to 6 . One indicates the highest and six the lowest (unimportance) importance of qualities. The evaluation is processed in a graphical form.

The assessment of qualities of innovation manager takes place in three steps:

- analysis of the qualities of present innovation managers,

- definition of ideal qualities of innovation manager,

- summary and synthesis of results.

The values acquired are evaluated by the arithmetic average rounding to two significant figures. The observed data is compiled into a spider graph for qualities of innovation manager, and a bar graph for an ideal innovation manager.

The questionnaires were sent to 30 representatives of companies operating in "Production, sale and operation of amusement and gaming technology" in the 
Czech Republic. 3 companies are engaged in production and sale of amusement and gaming technology, 27 companies are only providers of amusement and gaming technology.

The representatives were asked to distribute the questionnaires to innovation managers and to send them back in sealed envelopes (to protect anonymity and evaluation views). There were 7 questionnaires distributed to define ideal qualities of innovation manager, and 3 questionnaires to determine the qualities of present innovation managers in each company.

To define the position of innovation manager in company, literature search was used, in particular web links. It was proposed to involve an innovation manager into the organizational structure of companies operating in "Production, sale and operation of amusement and gaming technology".

\section{RESULTS}

A high-quality innovation manager must have in his team greater specialists than he is. He has to be a good negotiator and leader, which is basically more demanding than being an expert. Several studies, e.g. (Newton, 2008), (Němec, 2002), (Gido,Clements, 2003), (Taylor,2007), (McAvoy, 2008) and (Jaterková, 2008), have shown that many recognized experts have failed in this function. Their weakness is the excessive individualism, lack of interest in associates, lack of tact in the argumentation or hesitation. In other words, although they had the authority of an expert, they did not gain the authority of a leader. The innovation manager should have the following personal skills:

- Technical skills: These are technical skills, or the ability to use methods, knowledge and techniques of theoretical and practical disciplines, to use specialized personnel; a manager must have the specific skills of a technical nature the same as people he manages. Hence, he must be able to ensure the implementation of the work.

- Human skills: Ability to collaborate, understand and effectively communicate and motivate other staff.

- Conceptual skills: Ability to manage, integrate and mutually reconcile interests and activities taking place within the enterprise.

- Ability to empathize: To be able to feel with the position of the other, to know how to guess other person's needs. People are not machines. They have their opinions and concerns to be addressed. If we do not want to understand the other, nor we can not wonder that he does not understand us. Even the busiest innovation manager should make the time to speak to his people. A manager who is able to lower from his boss position and follow his personnel into the field, shows his friendliness and is much better perceived. Communication with employees at such tour should not 
go without recognition. Praise, if justified, is not only a recognition of the preceding, but motivates to meet the next challenge.

The qualities of ideal innovation manager are a very generic concept, because each company has different requirements of their leader. Most of them are still unaware, which of many qualities are just the most essential, and which should be favoured in their managers.

The survey of companies showed that of those evaluated qualities is independence currently the most necessary for an innovation manager (Figure 2). The independence was very closely followed by teamwork, which means that managers are both separate units and able to give good performance in teamwork as well. Communication with people placed as next. Economic knowledge is not felt as actual by managers at the moment. Other qualities ranked in the middle of an evaluation field in the following order: time independence, technical knowledge, management skills, readiness and flexibility in the end.

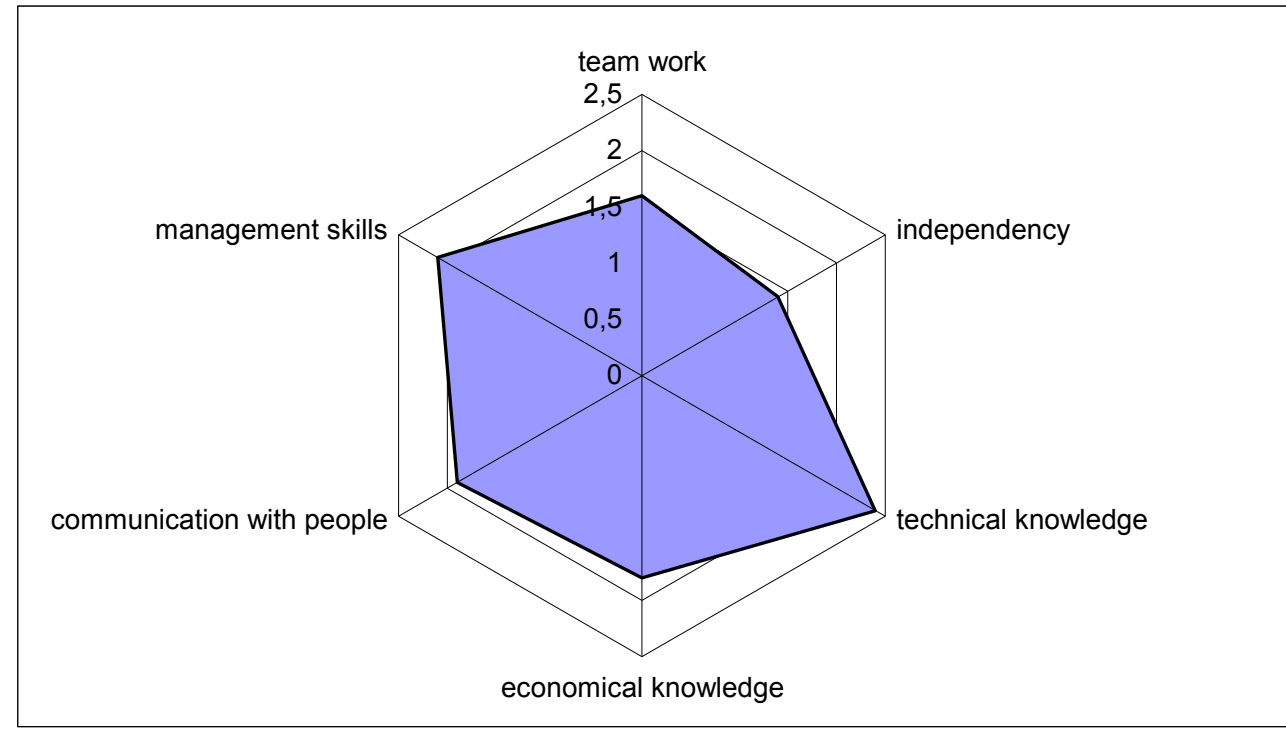

Figure 2 - Qualities of innovation manager

It is now evident what qualities are for future innovation managers of addressed companies indispensable, and which, on the contrary, are currently considered to be less important. Now we can order values according to importance:

- organizational skills,

- communicative,

- punctual,

- decisive,

- flexible,

- systematic, 
- thoughtful,

- expert in a given topic,

- optimistic,

- self-critical.

Graphic illustration of the ideal qualities of innovation manager (Figure 3) shows the necessary qualities for companies operating in "Production, sale and operation of amusement and gaming technology". Qualities that should an ideal innovation manager have at this moment are primarily "higher education, flexibility, organizational skills, orderliness, diligence and punctuality". Qualities such as "optimism, gender, or marital status" are for companies not so important.

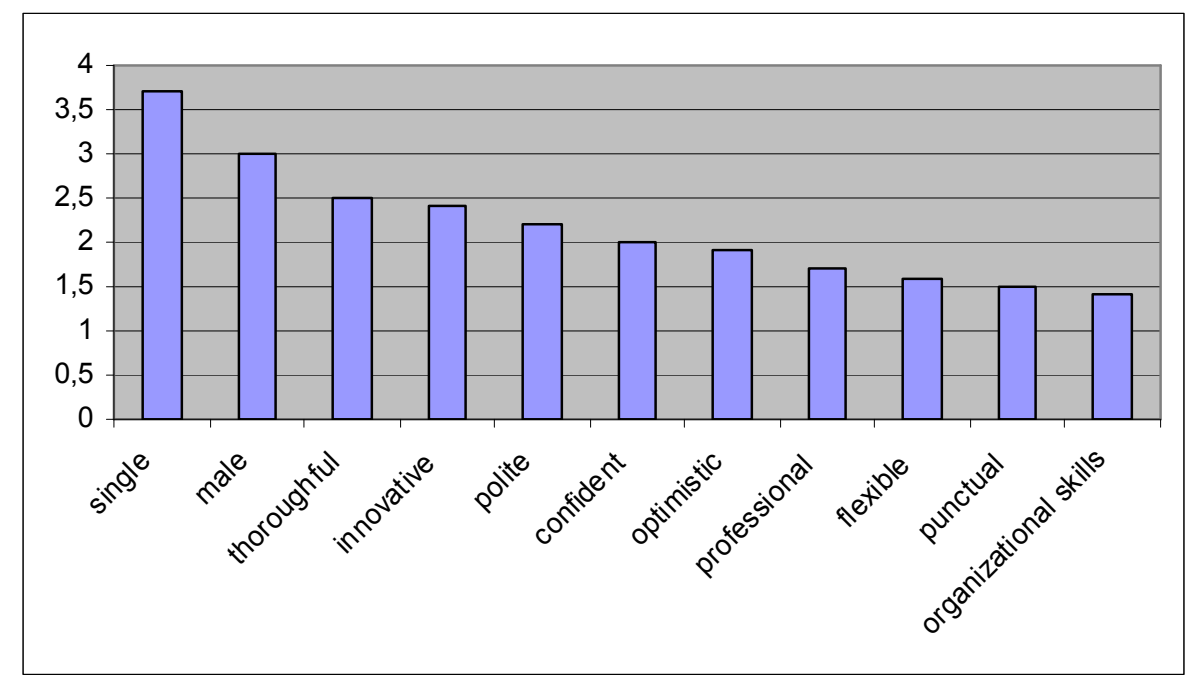

Figure 3 - Ideal qualities of innovation manager

\section{DISCUSSION}

\section{1 Qualities of Innovation Manager}

Whatever work a manager does, he is always viewed as a leader. An innovation manager has only a different job content and skills from other managers, but the basis is always the same. Manager's greatest weapon is his intelligence and intellectual powers, through which he dominates and controls his subordinates.

Each innovation manager should have in his set of skills organizational and strategic thinking, must be able to plan several weeks in advance and must know what and how to plan. Must also be able to professionally and properly lead and motivate people in their work, so that all the objectives are met. He must properly organize his work as well as the work of others and not only work but also his time. Among the essential skills are also a high degree of communicability and negotiation skills. 
Lately it is proven as very convenient to also invite customers to the innovation process. This step has undoubtedly its logic - innovations are provided mainly for customers. However, not in all cases is such initiative necessary and desirable - while making changes to internal communication in a company, the presence of our customers will prove as useless.

An innovation manager is not just a person who invents something new, it's the person who leads a team of creative people, it is up to him to combine and lead his team. The creative process is very complicated and it is necessary that a person in a managerial position is able to understand the long path to the desired innovation.

A successful innovation manager, whom his subordinates respect and at the same time are not intimidated by him, should be an emotionally balanced person with a certain degree of empathy. He should be also responsible, persistent and consistent, able to lead his team without any undue problems.

An innovation manager should have a creative personality. But not everyone is the right to invent new and new ways. There are people who do not have such thinking at all.

The creative personality is characterized by qualities such as activity, intuition, finding associations, the art of working with metaphors and inspiration, logic, energy, knowledge of the area in which the person operates and many others. Creative people can often exceed the rules and limits and are willing to take risks. They tend to be stubborn and persistent if they feel that what can not be achieved is actually achievable.

\subsection{Position of Innovation Manager in Company}

It should be noted that innovators are not only employees in research and development department. Yes, the representation of innovation and creative personalities is quite certainly greater than in other departments. Still, we may assume that inventions are not strictly defined to only a few chosen ones, any staff member can get an original and feasible idea, which will contribute to achieving the company goals (Chesbrough, 2006).

But we can not say that each manager of each department is an innovation manager. The innovation manager should be at the forefront of research and development department, because this is exactly the place where creativity is mostly concentrated. The innovation manager should be right there to acquire inventions of his team and be able to assert them at the top management.

The fundamental prerequisite for successful innovation management is his anchoring in the organizational structure. From a mere glance at the nature of innovation is clear that while most of the tasks and roles in the enterprise has its exact recipient, innovations are in this respect to some extent Cinderella who lacks her "assertor". Therefore, it is necessary to "artificially" create one. The 
question we must ask in such a thought is not "Create?" but "How to create it the most effectively?"

An interesting insight could be into the organizational structure of the ten largest innovative companies in global market. To compare them we will use a chart compiled by American magazine Fast Company, published in February 2010. The sequence is as follows according to (Fast Company, 2010):

- Facebook - a well known company providing a world-famous social network project. Recently it has broken the limit of 400 million users worldwide. Currently, the most widespread social network in the world with great influence.

- Amazon - a worldwide provider of Internet commerce in the world.

- Apple - a company operating in the field of computer technology. Led by charismatic Steve Jobs, considered to be one of the greatest innovators of the turn of the $20^{\text {th }}$ and $21^{\text {st }}$ century and innovation guru.

- Google - a provider of the world's most successful search engine google.com, beside search is involved in streaming video - Youtube.com server and many other services.

- Huawei - the largest provider of mobile communications services in Southeast Asia, slowly comes in on to Europe - awarded the contract to build 4G network in Norway. Was given precedence over giants such as Nokia or Ericsson.

- First Solar - the company is a leader in reducing the cost of generating electricity from solar energy. First it managed to reduce the price below $\$ 1$ per watt and anchored the price at $\$ 0.85$.

- PG\&E - a big energy company in the U.S.A. Produces electricity from all types of energy and is innovative in the view at the new possibilities of obtaining electricity. Has a contract for placement of panels into orbit and supply of electricity on Earth.

- Novartis - a Swiss manufacturer of medicines, the third largest company engaged in the manufacturing of drugs. Recently has come to market with several drugs to treat rare diseases and diseases difficult to cure.

- Walmart - the largest retail chain in the world. Started mainly in the U.S.A. Currently focusing on areas such as environmentally friendly light bulbs, reusable bags, better design of business places, or improving the supply chain.

- HP - a company famous mainly for computer and printing techniques.

All these companies are highly recognized innovators in their field. Their organizational structure is certainly adapted to the innovation process. An interesting fact is that all the above mentioned companies have a line structure. 
Its advantage is undoubtedly a clear definition of superiority and subordination. Mostly it involves firms founded by one or a few people who have undergone a very dynamic growth within a few years. As the most illustrious example we can mention Facebook, founded only in 2004, or Amazon and Google, founded in 1995 (Amazon) or 1998 (Google).

Only one of the above leaders in innovation has at the top a person in charge of innovation or development. We can therefore assume that the integration of an innovation manager to company top management is not appropriate and desirable. On the other hand, he should be equipped with a wide variety of competences and opportunities to work with people on both higher and lower positions in the company.

As the most suitable seems to be the separation from the company structure, to avoid pressure from both above and beneath. He should have clear authority to require and reward or punish the performance or non-performance of innovations or tasks that individual workers undertook (or which was imposed on them).

An innovation manager on the lowest level of management has a long way above to realize his job description. Suggestions for improvement will therefore have a long way to persons who will assess them and thus it will lead to their delay and lack of penetration in the onset of innovation process, which could competitors due to bureaucratic process implement much faster.

As a good opportunity I see the location of an innovative team in "Production, sale and operation of amusement and gaming technology" to the staff position. There is a clear possibility of integration into the structure and no need to worry about complex organizational structures, or lengthy process of his proposals for changes, as well as separation from the reality of company operation. Unfortunately, this type is not used by any companies mentioned above.

\section{CONCLUSION}

As current trends indicate, the world of productivity will be gradually replaced by the world of creativity to support newly emerging professions such as innovative engineer, creativity and innovation manager, etc. It is also necessary to realize that the problems of today are completely different, and for their solution is usually far less time than in the past.

The field surveys during the last period among the top managers of Czech companies have shown that the position of innovation manager is offered by approximately a quarter of firms only. While the vast majority representatives of the companies in the survey confirmed that their company has a processed innovation strategy. Quite logically, the question is who are the implementers, while innovation managers held accountable are in this direction a unique phenomenon indeed. Targeted training for this function is still completely lacking, which can result in our slow pace of innovation. In more than half of 
firms, by contrast, are in charge of innovation management several departments at once. Most often it is top management and engineering department. Solutions must be realistically applicable, as short time for implementation as possible and multiplying effect of the expected benefits. The journey from a generated idea to innovation realization is not easy. Still, time is a crucial factor of market success.

\section{REFERENCES}

CHESBROUGH, H.W. (2006), "Open Business Model: How to thrive in the new innovation landscape", Harvard Business School Press, 1st ed., 256 p. ISBN 14221-0427-3

CHRISTENSEN, C. J. (1997), "The innovator's dilemma: When new Technologies cause a great firms to fail", Harvard Business School Press. 1997. Boston. 225 p. ISBN 0-87584-585-1

FAST COMPANY STAFF. Most Innovative Companies. 2010, Retrieved 201003-28, from http: //www.fastcompany. com/mic/2010

GIDO, J., CLEMENTS, P.J. (2003) Succesful project management. Second edition. Thomson learning, 460 p., ISBN 0-324-07168-X

HOFBRUCKEROVÁ, Z. (2008), "Manažer kreativity a inovací", In Jakost pro život, 4/2008, Retrieved 2010-03-15 from

http://www.dtocz.cz/casopis.php?id_article $=311$

JATERKOVÁ, L. (2008), "8 praktických tipů, jak si vychovat dobrého manažera", Inovace.cz., Retrieved 2010-05-30, from http://www.inovace.cz/forbusiness/manazerske-dovednosti/clanek/8-praktickych-tipu--jak-si-vychovatdobreho-manazera-i-/

McAVOY, J. (2008), The role of project management in ineffective decision making within Agile software development projects. European journal on information system, 2008, vol. 8, pp. 372-383, Retrieved from ProQuest (DOI): http://proquest.umi.com/10.1057/efis.2009.22

NĚMEC, V. (2002), Projektový management. 1. edition, Praha: Grada Publishing, 184 p. ISBN 80-247-0392-0

NEWTON, R. (2008), Úspěšný projektový manažer, Translation A. Svozilová, 1. edition, Praha: Grada Publishing, 264 p., ISBN 978-80-247-2544-4

TAYLOR, J. (2007), Začínáme ř́dit projekty. 1. edition., Brno: Computer Press, 215 p., ISBN 978-80-251-1759-0 


\section{ABOUT THE AUTHOR}

Kateřina Hrazdilová Bočková, Ph.D. graduated from the Brno University of Technology, Faculty of Civil Engineering in the field of Economy and Management of Construction (2000). The postgraduate course at the same faculty focused on the study and application of project management. Since 2002 has worked at Tomas Bata University in Zlín, Faculty of Management and Economics, as a lecturer. Between 2004 - 2005 was responsible for leadership of the Department of Enterprise Economics. As guest lecturer of project management of PROFIMA Zlín (since 2004), an external consultant of several companies in the field of business strategy and a project manager for sporting events in her own aerobic studio Uherské Hradistě and VZP Oriflame Aerobics Tour. She is the author of numerous articles and books on project management. Since 2004 is a certified project manager and since 2006 a member of IPMA (Project Management Association). Faculty of Management and Economics, TBU in Zlín, Mostní 5139, 76001 Zlín, Czech Republic, bockova@fame.utb.cz. 